\title{
ANALYSIS FACTOR THAT INFLUENCE THE LEVEL OF DISABILITY IN LEPROSY PATIENTS IN KEDIRI LEPROSY HOSPITAL
}

\author{
Rima Kentarti ${ }^{1}$, Indasah ${ }^{2}$, Koesnadi $^{3}$ \\ ${ }^{1}$ Magister of Public Health Program, Stikes Surya Mitra Husada Kediri, Indonesia \\ ${ }^{2,3}$ Lecturer of Magister of Public Health Program, Stikes Surya Mitra Husada Kediri, Indonesia \\ Corresponding author: Rima Kentarti (rima_kentarti@yahoo.co.id)
}

\begin{abstract}
Leprosy if not handled carefully can cause disability, and the situation becomes a barrier for leprosy. The aim of the study was to analyze the regularity of treatment with MDT, self-care factors, paramedic role factors and family role factors that influence the level of disability of leprosy patients in Kediri leprosy hospital. The design was Cross Sectional. The population was leprosy patients. The sample size is 107 respondents using Simple Random sampling technique. Independent variables are family roles, officer roles, treatment, and self-care. the dependent variable is the level of disability. Data was collected using a questionnaire, analyzed using logistic regression tests with $\alpha \leq 0.05$. The results showed that Self-care $(p=0.002)$ is more dominant than the regularity of MDT treatment $(p=$ $0.031)$ to the level of hand disability. Self-care $(p=0,000)$ is more dominant than the regularity of MDT treatment $(p=0.006)$ to the level of leg defects in leprosy patients. The role of the family has more influence on the regularity of MDT treatment, the role of the officer has more influence on selfcare, self-care affects hand and foot disability more while the regularity of MDT treatment.
\end{abstract}

Keywords: Family role, leprosy, level of disability, officer role, self care

Copyright $@ 2019$ Stikes Surya Mitra Husada. All right reserved.

\section{INTRODUCTION}

Leprosy is an infectious disease which is still the most complex problem. Problems that exist not only in terms of medical, but also socio-economic, cultural problems. Leprosy if not handled carefully can cause disability, and the situation becomes a barrier for leprosy patients in living community life to meet their socio-economic needs (Kunoli, 2013).

Leprosy is one of 17 tropical diseases that are still neglected with a high incidence (World Health Organization, 2013). The number of people affected by leprosy reported from 38 countries in all WHO regions was 176,176 cases at the end of 2015 or 0.18 cases per 10,000 population with 211,973 new cases or 0.21 cases per 10,000 population (www.who.int, Leprosy Fact Sheet, Updated February 2017). The prevalence of leprosy in Indonesia in 2016 amounted to 0.71 cases per 10,000 population and the number of new cases was reported as 16,826 cases or 0.65 cases per 10,000 inhabitants. Based on elimination status, leprosy is divided into 2 groups, namely provinces that have not been eliminated and provinces that have achieved elimination. Provinces that have achieved elimination if the prevalence rate is $<1$ per 10,000 population, and East Java is included in 11 provinces that have not achieved leprosy elimination. (Ministry of Health, Republic of Indonesia, 2017).

In general, the prevalence rate in East Java has not seen a significant change (from 1.02 in 2015 to 1.04 in 2016) because in 2016 intensified case finding (ICF) activities were developed in 12 endemic districts leprosy which involves family participation to detect early symptoms of leprosy in family members. (Health Office of East Java Province, 2017).

In the effort to control leprosy, two main indicators were used, namely the number of new case detection rates (NCDR) and level II disability rates. The NCDR indicator illustrates the 
magnitude of the problem of leprosy or territory and one time while the level II defect rate illustrates the changes in the discovery of new cases of leprosy.

The main burden of leprosy is due to the disability caused by it, therefore the global target that must be achieved in 2015 is the rate of disability 2 per 100,000 population down $35 \%$ from the data in 2010, and the percentage of coverage of new cases of leprosy without disability in 2019 is 95\% (RI Ministry of Health, 2012 in Wewengkang, 2016). The number of new sufferers in East Java in 2016 was 3,991 patients (23.72\% nationally) with a proportion of Disability II of $11 \%$ (Health Office of East Java Province, 2017).

Leprosy Poly Kediri Leprosy Hospital specifically catered for patients with leprosy, including detection early leprosy, examination and treatment of leprosy and its complications (injuries and reactions), counseling for people affected by leprosy and family as well as medical rehabilitation examinations. Number of Leprosy Patient Visits at Outpatient Police Hospital. Kediri leprosy in 2016 was 3,948 visits, with the highest case of Borderline lepromatous leprosy disease as many as 3,429 cases (Kediri Hospital, 2017). Based on the results of a preliminary study conducted by researchers on October 3, 2017 at Kediri Leprosy Hospital, the number of visits of leprosy patients in the Outpatient Installation amounted to 19 patients, who were on MDT treatment totaling 2 sufferers. Through an examination at the Hospital Medical Rehabilitation Clinic. Kediri leprosy in 13 patients found that patients with disability level 0 amounted to 3 sufferers (23\%), level 1 defects amounted to 6 patients (46\%) and level 2 disabilities totaling 4 patients (31\%). From the report of P2 Leprosy Tribulan III Program in 2017 Hospital. Kediri leprosy, during the third round of the number of passive new patients as many as 16 patients, the number of new patients with disabilities as many as 7 patients and the number of patients who are still on MDT treatment at the end of the third tribulation were 61 patients. The average number of people affected by leprosy in the Outpatient Installation Hospital. Kediri leprosy per month is 149 patients while on average per month patients who do MDT treatment are 43 patients.

Therefore, it is expected that leprosy patients are able to treat MDT properly and regularly, and be able to carry out self-care. The role of health workers in the form of counseling and the role of the family in caring for sick family members and the use of assistive devices are also necessary in preventing further disability and disability. Analysis Factor That Influence The Level of Disability in Leprosy Patients In Kediri Leprosy Hospital.

\section{METHODS}

Design used in the study was Cross Sectional. The population was leprosy patients at the Outpatient Hospital of Kediri Leprosy Hospital. The sample size is 107 respondents using Simple Random sampling technique. Independent variables are family roles, officer roles, treatment, and selfcare. the dependent variable is the level of disability. Data was collected using a questionnaire, then the data were analyzed using logistic regression tests with a significance level of $\alpha \leq 0.05$.

\section{RESULTS}

\section{Test Statistics of Family Role Factors and Role of Officers on Regular Treatment of MDT}

Table 1. Test Results Model Fitting Information Role of Family and Officer Role on Regularity of Treatment of MDT

\begin{tabular}{lcccc}
\hline \multirow{2}{*}{ Model } & Model Fitting Criteria & \multicolumn{3}{c}{ Likelihood Ratio Tests } \\
\cline { 2 - 5 } & -2 Log Likelihood & Chi-Square & df & Sig. \\
\hline Intercept Only & 23,446 & & & \\
\hline Final & 15,683 & 7,763 & 4 &, 001 \\
\hline
\end{tabular}


Based on table 1. The test results show a significant value of $\mathrm{P}$-value $0.001<\alpha(0.05)$ so that $\mathrm{H} 0$ is rejected and $\mathrm{H} 1$ is accepted which means there is an influence of the independent variable family role and officer role on the dependent variable regularity of MDT treatment.

Table 2. Pseudo R-Square Test Results The Role of Families and the Role of Officers on Regular Treatment of MDT

\begin{tabular}{cc}
\hline Cox and Snell &, 070 \\
\hline Nagelkerke &, 391 \\
\hline McFadden &, 103 \\
\hline
\end{tabular}

Based on table 2. Nagelkerke found that a result of 0.391 means that the independent variables of family roles and roles influence order MDT treatment in leprosy patients was $39.1 \%$, while $60.9 \%$ was influenced by other factors not included in the model testing.

Table 3. Likelihood Ratio Test Results of the Role of Families and Officers' Roles on the Regularity of Treatment of MDT

\begin{tabular}{lcccc}
\hline \multirow{2}{*}{ Effect } & Model Fitting Criteria & \multicolumn{3}{c}{ Likelihood Ratio Tests } \\
\cline { 2 - 5 } & $\begin{array}{c}-2 \text { Log Likelihood of } \\
\text { Reduced Model }\end{array}$ & Chi-Square & df & Sig. \\
\hline Intercept & $15,683^{\text {a }}$ &, 000 & 0 &. \\
\hline Peran_Keluarga & 19,503 & 3,820 & 2 &, 008 \\
\hline Peran_Petugas & 21,731 & 6,048 & 2 &, 009 \\
\hline
\end{tabular}

Based on Table 3.the results obtained $\mathrm{p}$ value was lowest/ smallest one is the role of the family variables $(p=0.008)$ compared with the variable officer role $(p=0.009)$ so it can be concluded that the variable family role is the dominant factor that influences the regularity of MDT treatment in leprosy patients in Kediri Leprosy Hospital.

\section{Statistic test of Family Roles Factors and Role of Officers on Self-Care}

Table 4. Test Results Model Fitting Information of Family Role and Officer Role in Self-Care

\begin{tabular}{ccccc}
\hline \multirow{2}{*}{ Model } & Model Fitting Criteria & \multicolumn{3}{c}{ Likelihood Ratio Tests } \\
\cline { 2 - 5 } & -2 Log Likelihood & Chi-Square & df & Sig. \\
\hline Intercept Only & 176,341 & & & \\
\hline Final & 20,524 & 155,817 & 8 & 000 \\
\hline
\end{tabular}

Table 4. Based on test results obtained showed a significant value $0.000 \mathrm{P}$-value $<\alpha(0.05)$ so $\mathrm{H} 0$ is rejected and $\mathrm{H} 1$ accepted which means no independent variables influence the role of family and the role of the officer on the dependent variable self-care.

Table 5. Pseudo R-Square Test Results the Role of Families and the Role of Officers on SelfCare

\begin{tabular}{cc}
\hline Cox and Snell &, 767 \\
\hline Nagelkerke &, 905 \\
\hline McFadden &, 774 \\
\hline
\end{tabular}

Based on Table 5. Nagelkerke obtained results of 0.905 which means that the independent variables of family roles and the role of officers affect self-care leprosy patients were $90.5 \%$, while $9.5 \%$ were influenced by other factors not included in the model testing. 
Table 6. Likelihood Ratio Test Results of the Families Role and Officers Role in Self-Care

\begin{tabular}{lcccc}
\hline \multirow{2}{*}{ Effect } & Model Fitting Criteria & \multicolumn{3}{c}{ Likelihood Ratio Tests } \\
\cline { 2 - 5 } & $\begin{array}{c}-2 \text { Log Likelihood of } \\
\text { Reduced Model }\end{array}$ & Chi-Square & df & Sig. \\
\hline Intercept & $20,524^{\text {a }}$ &, 000 & 0 &. \\
\hline Peran_Keluarga & 43,196 & 22,672 & 4 &, 005 \\
\hline Peran_Petugas & 118,899 & 98,375 & 4 &, 000 \\
\hline
\end{tabular}

Based on table 6. the results of the p-value lowest / smallest are found in the officer role variable $(p=0,000)$ compared to the family role variable $(p=0.005)$ so that the variable the role of officers is the dominant factor that influences self-care in leprosy patients in Kediri leprosy hospital.

\section{Statistics test of Regularity MDT Treatment factor And self care to level of eye Disability}

Table 7. Test Results Model Fitting Information MDT Treatment And self care to Level of eye Disability

\begin{tabular}{lcccc}
\hline \multirow{2}{*}{ Model } & Model Fitting Criteria & \multicolumn{3}{c}{ Likelihood Ratio Tests } \\
\cline { 2 - 5 } & -2 Log Likelihood & Chi-Square & df & Sig. \\
\hline Intercept Only & 14,365 & & & \\
\hline Final & 10,366 & 3,999 & 6 &, 677 \\
\hline
\end{tabular}

Based on table 7. The test results show a significant value of P-value $0.677>\alpha(0.05)$ so that $\mathrm{H} 0$ is accepted and $\mathrm{H} 1$ is rejected which means there is no effect of independent variables on MDT treatment and self-care dependent variable level of eye disability.

Table 8. Pseudo R-Square Test Results of Regularity MDT Treatment and Self-Care to Level of eye Disability

\begin{tabular}{cc}
\hline Cox and Snell &, 037 \\
\hline Nagelkerke &, 093 \\
\hline McFadden &, 074 \\
\hline
\end{tabular}

Based on Table 8. Nagelkerke obtained a result of 0.093 which means that the independent variable of MDT treatment and self-care affect the rate of eye disability in leprosy patients by $9.3 \%$, while $90.7 \%$ is influenced by other factors not included in the model testing.

Table 9. Likelihood Ratio Test Results Regularity of MDT Treatment and self care to Level of eye Disability

\begin{tabular}{lcccc}
\hline \multirow{2}{*}{ Effect } & Model Fitting Criteria & \multicolumn{3}{c}{ Likelihood Ratio Tests } \\
\cline { 2 - 5 } & $\begin{array}{c}\text { Model } \\
\text { M Log Likelihood of Reduced }\end{array}$ & Chi-Square & df & Sig. \\
\hline Intercept & $10,366^{\mathrm{a}}$ &, 000 & 0 &. \\
\hline Pengobatan & 11,691 & 1,325 & 2 &, 516 \\
\hline Perawatan_Diri & 12,894 & 2,528 & 4 &, 640 \\
\hline
\end{tabular}

Based on table 9 the results showed that the regularity of MDT treatment $(\mathrm{p}=0.516)$ and selfcare $(\mathrm{p}=0.640)$ both $>\alpha(0.05)$ so that it can be concluded the regularity of MDT treatment and treatment self does not influence the level of eye disability in leprosy patients in Kediri leprosy hospital. 
4. The Statistics Test of Regularity MDT Treatment Factors and self care to Level of hand Disability

Table 10 Test Results Model Fitting Information on MDT Treatment Regularity and self care for Level of Hand Disability

\begin{tabular}{lcccc}
\hline \multirow{2}{*}{ Model } & Model Fitting Criteria & \multicolumn{3}{c}{ Likelihood Ratio Tests } \\
\cline { 2 - 5 } & -2 Log Likelihood & Chi-Square & df & Sig. \\
\hline Intercept Only & 39,870 & & & \\
\hline Final & 29,034 & 10,835 & 6 & 004 \\
\hline
\end{tabular}

Based on table 10, the test results show a significant value of $\mathrm{P}$-value $0.004<\alpha(0.05)$ so that $\mathrm{H} 0$ is rejected and $\mathrm{H} 1$ is accepted which means there is an influence of independent variables on MDT treatment and self-care towards the dependent variable level of hand disability.

Table 11 Pseudo R-Square Test Results Regularity of MDT Treatment and Self-Care to Levels of Hand Disability

\begin{tabular}{cc}
\hline Cox and Snell &, 096 \\
\hline Nagelkerke &, 410 \\
\hline McFadden &, 048 \\
\hline
\end{tabular}

Based on table 11 the p-value value is lowest / smallest found in the self-care variable ( $\mathrm{p}=$ $0.002)$ compared with the regularity of MDT treatment variables $(p=0.031)$ so that it can be concluded that the variable self-care is the dominant factor affecting the level of hand disability in leprosy patients in Kediri leprosy hospital.

5. Test Statistic Regularity factor MDT Treatment And self care to Level of Foot Disability

Table 12. Fitting Information Model MDT Treatment And Self Care to Level of Foot Disability

\begin{tabular}{lcccc}
\hline \multirow{2}{*}{ Model } & Model Fitting Criteria & \multicolumn{3}{c}{ Likelihood Ratio Tests } \\
\cline { 2 - 5 } & -2 Log Likelihood & Chi-Square & df & Sig. \\
\hline Intercept Only & 64,593 & & & \\
\hline Final & 20,834 & 43,759 & 6 &, 000 \\
\hline
\end{tabular}

Based on Table 12 shows the test results obtained significant value $0.000 \mathrm{P}$-value $<\alpha(0.05)$ so $\mathrm{H} 0$ is rejected and $\mathrm{H} 1$ accepted which means that there is the influence of the independent variable regularity MDT treatment and self-care on level of foot disability.

Table 13 Pseudo R-Square Test Results Regularity of MDT Treatment and Self-Care to Level of Foot Disability

\begin{tabular}{cc}
\hline Cox and Snell &, 336 \\
\hline Nagelkerke &, 412 \\
\hline McFadden &, 242 \\
\hline
\end{tabular}

Based on Table 13 in Nagelkerke, results obtained at 0.412 means that the independent variables of MDT treatment and self-care affect levels foot disability in leprosy patients was $41.2 \%$, while $58.8 \%$ was influenced by other factors not included in the model testing. 
Table 14 Likelihood Ratio Test Results of Regularity of MDT Treatment and self care to level of Foot Disability

\begin{tabular}{lcccc}
\hline \multirow{2}{*}{ Effect } & \multicolumn{3}{c}{ Model Fitting Criteria } & \multicolumn{3}{c}{ Likelihood Ratio Tests } \\
\cline { 2 - 5 } & $\begin{array}{c}\text {-2 Log Likelihood of Reduced } \\
\text { Model }\end{array}$ & Chi-Square & df & Sig. \\
\hline Intercept & $20,834^{\mathrm{a}}$ &, 000 & 0 &. \\
\hline Pengobatan & 23,530 & 2,697 & 2 &, 006 \\
\hline Perawatan_Diri & 63,649 & 42,815 & 4 &, 000 \\
\hline
\end{tabular}

Based on Table 14 showed value $p$-value the lowest/ smallest contained in the self-care variables $(p=0.000)$ compared with a variable regularity MDT treatment $(p=0.006)$ so it can be concluded that the variable self-care is the dominant factor affecting the level of foot disability in leprosy patients in the Kediri leprosy hospital..

\section{DISCUSSION}

Based on the results of the study, it was found that out of 107 respondents most respondents had a rate of eye defects with a defect rate of 0 as many as 101 respondents (94.4\%), most respondents had a handicap rate with a defect rate of 0 as many as 46 respondents $(43 \%)$ were disabled hands with a defect rate of 1 as many as 40 respondents $(37.4 \%)$, most respondents had a level of disability of the foot with a defect rate of 1 as many as 73 respondents $(68.2 \%)$.

The results showed that the majority of respondents had male sex with a leg 1 defect rate of 51 respondents $(47.7 \%)$, most respondents had married marital status with 0 eye defects, namely 78 respondents $(72.9 \%)$, the highest number of respondents were private jobs with a 1 -foot defect rate of 29 respondents $(27.1 \%)$.

Leprosy defects are abnormal conditions of the physical and physiological body and loss of some body structure and function caused by leprosy. According to WHO (1982) the term limitation in leprosy defects is Handicap, which is any loss or abnormality in structure or function that is psychological, physiological or anatomic. Disability, namely all limitations or lack of ability (due to impairment) to carry out activities within the limits of normal life for humans. This disability is Impairment objectivity, disruption at the individual level including its inability in daily activities. Impairment is a setback in an individual (due to impairment or disability) that limits or hinders the completion of normal tasks that depend on age, sex, and socio-cultural factors. This handicap is the effect of leprosy that has social, economic and cultural impacts. If you hear the word leprosy, what is imagined is a skin disease that will eventually cause frightening mutilation. Even though nerve damage has occurred there is still a possibility to avoid further damage or disability (Ministry of Health, 2014).

Based on the results of the study it was found that most respondents had a level of leg defects with a level of disability 1 . Most patients came with a condition that there had been a disability that was in the eyes, hands, or foott. Based on Manyullei (2012) said that the factors that can be related to disability of lepers are self care of leprosy patients. According to Purwanto (2016) the magnitude of the opportunity for MB type sufferers to suffer from disabilities compared to PB types is related to the discovery of BTA (Basil Acid Resistant) in the MB type, whereas in the PB type it is not found (negative).

Based on the results of the study that the majority of elementary school respondents with foot 1 defect rate were as many as 44 respondents $(41.1 \%)$, low education resulted in a lack of knowledge of people affected by leprosy, so that leprosy sufferers did not understand the adverse consequences of leprosy.

Most of the respondents were male with foot 1 defect rate, men had more activities outside the home than women, so men were more vulnerable to contracting leprosy.

The source of leprosy transmission is sufferers of MB type, so that if this type of patient is immediately found and treated, the source of transmission to other people can be disconnected, because with treatment the leprosy germs do not have damage to body tissues, even germs will die, 
signs of disease become less active until it finally disappears. There are some patients who experience limitations and inability to move due to the disability of leprosy so that they interfere with daily life activities or disturbances that limit or hinder the completion of tasks that are usually done. With adequate health facilities and medical personnel, this damage to the eyes, hands and feet can actually be prevented, if recognized and treated early.

Disability of leprosy patients can be described as a disruption in carrying out daily life if the disability decreases physical function so as to limit or hinder the completion of activities normally. Damage to nerve function in leprosy patients is still possible to avoid further damage or disability if getting proper treatment and care.

Analyzing the regularity of MDT treatment, self-care, the role of officers, the role of the family that affects the level of disability of lepers in hospitals. Based on the results of the logistic regression test variable family role and the role of officers on the regularity of MDT treatment, obtained a significant value of P-value $0.001<\alpha(0.05)$ which means that there is an influence of the independent variable family role and the role of officers on the MDT treatment dependent variable.

The lowest / smallest $\mathrm{p}$-value value is found in the family role variable $(\mathrm{p}=0.008)$ compared to the officer role variable $(\mathrm{p}=0.009)$ so it can be concluded that family role variables are the dominant factors that influence the regularity of MDT treatment in leprosy patients in Kediri leprosy hospitals. This is consistent with Yuli Astuti's (2014) study which states that there is a meaningful relationship between family support and compliance with leprosy patients who go to treatment but is different from the results of Yuli Astuti's study (2014) which states that there is no significant relationship between health care support and compliance lepers come for treatment. Likewise, the research of Ma'rifatul Khotimah (2014) also states that family support and the role of health workers are related to medication compliance in leprosy sufferers in Blora Regency. The role of the family influences the regularity of treatment in accordance with Santoso's theory (2012) which states that the family has an important influence on the formation of an individual's individual identity and feelings of self-esteem so that the patient tries to recover quickly. Based on the results of the logistic regression test family role variables and the role of the officer on self-care obtained a significant value of P-value $0.000<\alpha$ $(0.05)$ means that there is an influence of the independent variable family role and the role of officers on the dependent variable of self-care. The lowest / smallest p-value value is found on the role role variable $(\mathrm{p}=0,000)$ compared to the family role variable $(\mathrm{p}=0,005)$ so it can be concluded that the variable role of the officer is the dominant factor affecting self-care in leprosy patients in the hospital. Kediri leprosy. In accordance with the results of the research by Alif Farkhanan Nur Laili (2016), there is a relationship between family support and self-care of lepers.

Based on the results of the study, the role of officers was more dominant than the role of the family in self-care in leprosy patients in the Kediri leprosy hospital. This shows that structured education from officers towards treatments performed significantly affects self-care in leprosy patients. Because the role of officers in controlling leprosy is an effort to improve the ability of patients through learning and can help themselves in efforts to control leprosy and self-care. Based on the results of the logistic regression test the regularity of MDT treatment and self-care variables on the level of eye defects obtained a significant value of P-value $0.677>\alpha(0.05)$ which means there was no effect on the independent variable MDT treatment and self-care towards the dependent variable eye defect rate.

The results of the $\mathrm{p}$-value of MDT treatment regularity $(\mathrm{p}=0.516)$ and self-care $(\mathrm{p}=0.640)$ both $>\alpha(0.05)$ so that it can be concluded that the regularity of MDT treatment and self-care does not affect the level of eye disability in leprosy patients in the Kediri leprosy hospital. Based on the results of the study it was found that the regularity of MDT treatment and self-care did not affect the level of eye defects in leprosy patients in the Kediri leprosy hospital. This is because some respondents when they came to the hospital had experienced disability. According to Purwanto (2016) data on the distribution of leprosy sufferers contributes to the discovery of leprosy sufferers and also how to prevent disability of new leprosy sufferers. The absence of early identification or initial screening that makes patients come to hospital has experienced disability. Based on the results of the logistic regression test the regularity of MDT treatment and self-care variables on the level of hand disability obtained a significant value of P-value $0.004<\alpha(0.05)$ which means there is an independent variable influence on the regularity of MDT treatment and self-care on the dependent variable of hand disability. 
The lowest / smallest $p$-value value is found in the self-care variable $(p=0.002)$ compared to the MDT treatment regularity variable $(\mathrm{p}=0.031)$ so it can be concluded that the self-care variable is the dominant factor that affects the hand disability rate in leprosy patients in the Kediri leprosy hospital. Based on the results of the logistic regression test the regularity of MDT treatment and selfcare variables on the level of foot defects obtained a significant value of P-value $0.000<\alpha(0.05)$ which means that there is an independent variable influence on the regularity of MDT treatment and self-care against the dependent variable.

\section{CONCLUSION}

Based on the results of research on " Analysis Factor That Influence The Level of Disability in Leprosy Patients In Kediri Leprosy Hospital, the following conclusions are obtained:

1. Most respondents do MDT treatment regularly as many as 95 respondents $(88.8 \%)$.

2. Most respondents have good self-care as many as 63 respondents $(58.9 \%)$.

3. Most respondents have a good family role of 57 respondents $(53.3 \%)$.

4. Most of the respondents had a good role of Officer as many as 58 respondents $(54.2 \%)$.

5. Most respondents had eye disability level with a disability level of 0 as many as 101 respondents $(94.4 \%)$, hand disability level with 0 defect rate as many as 46 respondents (43\%), foot disability level with disability level 1 as many as 73 respondents $(68.2 \%)$.

a. There is an influence between the role of the family and the role of the officer on the regularity of MDT treatment in leprosy patients, where the results of $\mathrm{p}$ value $0.001<\alpha=0.05$. The most dominant factor that influences the regularity of MDT treatment in leprosy patients is the role of the family with the results of $p$-value $=0.008$.

b. There is an influence between the role of the family and the role of the officer on self-care in leprosy patients, where the results of $\mathrm{p}$ value $0.000<\alpha=0.05$. The most dominant factor affecting self-care in leprosy patients is the role of officers with the results of $p$-value $=0,000$.

c. There is no influence between the regularity of MDT treatment and self-care towards the level of eye disability, where the results of $\mathrm{p}$ value $0.677>\alpha=0.05$.

d. There is an influence between the regularity of MDT treatment and self-care towards the level of hand disability, where the results of p value $0.004<\alpha=0.05$. The most dominant factor that influence the level of hand disability is self-care with the results of $p$-value $=0.002$.

e. There is an influence between the regularity of MDT treatment and self-care towards the level of foot disability, where the results of p value $0.000<\alpha=0.05$. The most dominant factor that influence the level of foot disability is self-care with the results of $p$-value $=0,000$.

\section{SUGGESTION}

Persons affected by leprosy can regularly take MDT medication until they are finished and carry out self-care regularly so that there is no disability or for those who have already been disabled so that the disability does not increase in weight. Families of people affected by leprosy must continue to support the treatment of leprosy sufferers to completion and also support both information, instrumental and help carry out leprosy self-care at home, to improve the quality of health for lepers. Coordinate with the District / City Health Office to hold training strategies for patient discovery and treatment of disability in leprosy patients for the officer in charge leprosy program at the Puskesmas. Health workers at the hospital to improve health education and self-care training in leprosy patients at home to leprosy patients and their families. Monitoring the treatment of leprosy patients for patients who are not regularly treated. Future researchers are expected to develop the results of this study by examining other factors that affect the level of disability of leprosy patients who have not been studied in this study in order to obtain optimal results. 


\section{REFERENCES}

Andri, M., Indar, \& Maidin, A. (2013). Pengaruh mutu pelayanan kesehatan terhadap kepatuhan berobat pasien kusta di Puskesmas Kota Palu.

Astuti, Y. (2014). Faktor-faktor yang Berhubungan dengan Kepatuhan Penderita Kusta untuk Datang Berobat Teratur di Wilayah Jakarta Selatan Tahun 2014. Jurnal Ilmiah Widya, Volume 4 Nomor 2 Agustus Desember 2017.

Ariani, S. (2015). Stop!Kanker. Yogyakarta Istana Medika.

Djuanda, A. (2010). Ilmu Penyakit Kulit dan Kelamin, Fakultas Kedokteran Universitas Indonesia Jakarta.

Dinkes. Prov. Jatim. (2017). Profil Kesehatan Provinsi Jawa Timur 2016. Dinas Kesehatan Provinsi Jawa Timur.

Estiningsih. (2016). Faktor-faktor yang berhubungan dengan perawatan diri dalam upaya pencegahan kecacatan penderita kusta. Undip.

Guimaraes, P., A. (2009). Prinsiples of Nanomagnetism, German, Springer. Halliday.

Hartanti, \& Dwi, R. (2015). Perawatan diri pasien kusta. Stikes Muhammadiyah Pekajangan Pekalongan. Jurnal Ilmiah KesehatanVol VII No. 1.

Kemenkes RI. (2017). Profil Kesehatan Indonesia Tahun 2016. Sekretariat Jenderal Kementerian Kesehatan RI.

Kemenkes. RI. (2014). Pedoman Nasional Program Pengendalian Penyakit Kusta. Direktorat Jenderal Pengendalian Penyakit dan Penyehatan Lingkungan Kementerian Kesehatan RI.

Khotimah, M. (2014). Hubungan Antara Dukungan Keluarga Dan Peran Petugas Kesehatan Dengan Kepatuhan Minum Obat Kusta. Unnes Journal of Public Health, 2, pp. 1-5.

Kunoli, F., J. (2013). Pengantar Epidemiologi Penyakit Menular. Trans Info Media Jakarta.

Laili, A., F., N. (2016). Hubungan Dukungan Keluarga Dan Pengetahuan Terhadap Perawatan Diri Penderita Kusta Di Puskesmas Grati Tahun 2016. The Indonesian Journal of Public Health, Vol. 12 No. 1, Desember 2016: 13-226.

Manyullei. (2012). Gambaran faktor yang berhubungan dengan penderita kusta di Kecamatan Tamalate Kota Makassar. Archive of Community Health. Unud.

Notoatmodjo, \& Soekidjo. (2011). Kesehatan Masyarakat: Ilmu \& Seni. Jakarta: PT. Rineka Cipta.

Notoatmodjo, \& Soekidjo. (2010). Metodologi Penelitian Kesehatan. Jakarta: Rineka Cipta.

Nursalam. (2015). Metodologi Penelitian Ilmu Keperawatan Pendekatan Praktis, edisi 4 Salemba Medika Jakarta.

Ola, P. (2015). Faktor-faktor yang berhubungan dengan keberhasilan pengobatan pada pasien kusta di Puskesmas Sukadami Tahun 2015. Jurnal Ilmiah Keperawatan Stikes Medika Cikarang.

Purwaningsih, W. (2012). Asuhan Keperawatan Jiwa. Yogjakarta Nuha Medika. 
Purwanto. (2016). Cara Penemuan Penderita Kusta Baru dan Tingkat Kecacatan di Provinsi Lampung. jurnal.poltekkes.

RS. Kusta Kediri. (2017). Profil Rumah Sakit Kusta Kediri Tahun 2016.

Sugiyono. (2013). Metode Penelitian Kuantitatif, Kualitatif dan R\&D. Bandung: Alfabeta.

Suprajitno. (2016). Asuhan Keperawatan Keluarga: Aplikasi dalam praktik,. Jakarta: EGC.

Susanto, T., Sahar, J., \& Permatasari, H. (2013). Perawatan Klien Kusta di Komunitas. Trans Info Media Jakarta.

Susanto, Tantut. (2012). Buku Ajar Keperawatan Keluarga, Aplikasi Teori Pada Praktik Asuhan Keperawatan Keluarga. Trans Info Media Jakarta.

Wewengkang, K., Henry M., F., \& Dina, V. (2016). Pencegahan Kecacatan Akibat Kusta di Kota Manado. Jurnal Kedokteran Komunitas dan Tropik: Volume 4 Nomor 2.

Widoyono. (2012). Penyakit tropis epidemiologi, penularan, pencegahan dan pemberantasannya. Erlangga Jakarta.

Wulandari. (2011). Efektifitas pelatihan perawatan diri terhadap dukungan emosional dan instrumental keluarga penderita kusta. Jurnal Keperawatan. Fiskes Unsoed.

Zakiyyah, N.,.R., Budiono, I., \& Zainnafree, I. (2015). Faktor-faktor yang Berhubungan Dengan Tingkat Kepatuhan Minum Obat Penderita Kusta di Kabupaten Brebes. Unnes Journal Of Public Health, 3, pp.58-66. 